\section{EL PENSAMIENTO DE IGNACIO ELLACURÍA ACERCA DE LA FUNCIÓN SOCIAL DE LA UNIVERSIDAD}

\author{
José Sols Lucia \\ IQS - Instituto Químico de Sarriá \\ Universidad Ramon Llull \\ jose.sols@iqs.edu
}

\section{IGNACIO ELLACURÍA'S THINKING ON UNIVERSITY'S SOCIAL FUNCTION}

Cómo citar este artículo/Citation: Sols Lucia, J. (2016). El pensamiento de Ignacio Ellacuría acerca de la función social de la universidad. Arbor, 192 (782): a362. doi: http://dx.doi. org/10.3989/arbor.2016.782n6007

Recibido: 04 noviembre 2014. Aceptado: 25 agosto 2015.
RESUMEN: En un contexto histórico sorprendente, el de El Salvador (Centroamérica) de los años setenta y ochenta, con revueltas populares contra el sistema socioeconómico poscolonial, con una guerra civil que duró diez años, con asesinatos masivos de población civil, Ignacio Ellacuría piensa de un modo nuevo la función social de la universidad, partiendo de su experiencia como Director del Departamento de Filosofía de la UCA (Universidad Centroamericana) de El Salvador, primero, y como Rector de esa misma universidad, después. Concibe la universidad, en particular la de inspiración cristiana, como es el caso de la UCA, como una institución toda ella dedicada al análisis exhaustivo de la realidad histórica - tanto de la realidad de la naturaleza en la que habita el hombre, como de la realidad social, económica y política - y a la transformación de esa realidad para conducirla hacia una sociedad futura en la que todos los hombres sean respetados en su dignidad humana. Con ello, la universidad - tanto en su docencia, como en su investigación, como en su proyección social - constituye el momento teórico de los movimientos históricos de liberación, pero para ello su aportación debe ser tan universitaria como realista, lejos de las universidades políticamente desubicadas y de las universidades reconvertidas en simple local de agitación subversiva.

PALABRAS CLAVE: Ignacio Ellacuría; UCA-Universidad Centroamericana; El Salvador (Centroamérica); Función social de la universidad; Teología de la Liberación.
Copyright: (c) 2016 CSIC. Este es un artículo de acceso abierto distribuido bajo los términos de la licencia Creative Commons Attribution (CC BY) España 3.0.
ABSTRACT: In the convulsive historical context of El Salvador (Central America) during the 1970s and 1980s, characterized by popular uprisings against the postcolonial socioeconomic system, the ten year Salvadorean civil war and the mass murder of civilians, Ignacio Ellacuría rethinks the University's social function based on his experience as Head of the Department of Philosophy and, then, as Rector of the Central American University (UCA) in El Salvador. His conception of the university, and in particular of universities of Christian inspiration, is that of an institution devoted to an in-depth analysis of historical reality -in terms of the human habitat as well as the social, economic and political reality - and the transformation of this reality towards a future society respectful of the dignity of every human being. In this sense, the university, understood in the broadest sense - teaching, research and social mobility-, represents the theoretical moment of historical liberation movements. However, to fulfill this goal the university contribution should not only be academic but should, also, be firmly rooted in reality, and not external to the political framework or merely a place for subversive unrest.

KEYWORDS: Ignacio Ellacuría, UCA-Universidad Centroamericana; El Salvador (Central America); University's social function; Liberation Theology. 


\section{INTRODUCCIÓN: IGNACIO ELLACURÍA Y SU CONTEXTO HISTÓRICO}

No cabe duda de que el pensamiento de cualquier autor está condicionado, de un modo u otro, por su contexto histórico, lo cual ha sido ampliamente estudiado por la hermenéutica moderna a través de las obras de Friedrich Schleiermacher, Wilhelm Dilthey, Martin Heidegger, Hans-Georg Gadamer o Paul Ricoeur, entre otros (Sols, 2003, pp. 11-26), sin olvidar la imprescindible aportación que al respecto ha hecho la teología cristiana a través de autores como Rudolf Bultmann, Ernst Fuchs, Gerhard Ebeling, Wolfahrt Pannenberg, Johann Baptist Metz o Ignacio Ellacuría (Sols, 2003, pp. 27-45). Precisamente, en el caso de este último, ese contexto se sitúa en el núcleo de su pensamiento, dado que Ellacuría entiende que la filosofía tiene una doble función: en un primer momento, aprehender la realidad a través de la inteligencia sentiente, para, en un segundo momento, tratar de transformarla, algo que se ubica explícitamente en la posteridad de Karl Marx. Ellacuría, aun siendo consciente de su deuda intelectual con el marxismo, con el que nunca llegó a identificarse plenamente, prefirió seguir la estela del pensamiento de Xavier Zubiri, de quien llegó a ser su más estrecho colaborador.

Ignacio Ellacuría (1930-1989), ${ }^{1}$ jesuita vasco, español, fue enviado como novicio a El Salvador, Centroamérica, cuando sólo tenía 18 años, en 1948, en una época en la que la región centroamericana en general y El Salvador en particular no parecían zonas problemáticas, dado que la fuerte represión del ejército salvadoreño al incipiente comunismo latinoamericano, en 1932, que había costado cerca de 30.000 muertos, quedaba ya muy lejos, y todavía no se atisbaba en el horizonte el tenso movimiento de izquierdas de los años sesenta. Nadie podía sospechar por tanto, en aquel momento, que aquel muchacho vestido con sotana llegaría a producir un pensamiento filosófico, teológico y político poderoso en pleno proceso revolucionario salvadoreño, ni que llegaría a ser el mediador principal en una guerra civil (1981-1991) que constituiría el mayor quebradero de cabeza de la política exterior de la Administración norteamericana Reagan-Bush durante los ochenta.

Tras una larga formación, que le hizo pasar por las aulas de Quito (Ecuador), donde estudió Humanidades y Filosofía, Innsbruck (Austria), donde estudió Teología, y Madrid, donde realizó su doctorado en filosofía sobre el pensamiento de Xavier Zubiri, al que le uniría una estrecha amistad y una colaboración intelectual aún más estrecha hasta la muerte de este, en 1983, Ellacuría aterrizó definitivamente en suelo salvadoreño en 1969, donde viviría hasta su muerte por asesinato, en 1989, un período de veinte años, largo pero sobre todo intenso. Solía viajar cada año a España durante las vacaciones salvadoreñas para trabajar con Zubiri en Madrid y poner a punto para publicación los textos filosóficos de su maestro y amigo.

Así, Ellacuría dedicó los últimos veinte años de su vida a trabajar intensamente en la Universidad Centroamericana (UCA) de El Salvador, entre 1969 y 1989, diez como Director del Departamento de Filosofía y los otros diez como Rector de la universidad, hasta que fue asesinado por el ejército salvadoreño junto a cinco compañeros jesuitas y dos empleadas del servicio doméstico, el 16 de noviembre de 1989. Sus veinte años en la UCA - una universidad de la Compañía de Jesús, no católica, sino de inspiración cristiana (Ellacuría, 1999b) (opción que le permitía tener autonomía con respecto a la jerarquía de la Iglesia Católica, en aquel tiempo demasiado cercana a la oligarquía nacional y al ejército) - coincidieron con un período de enorme ebullición política en el subcontinente latinoamericano (años sesenta, setenta y ochenta), en concreto, en El Salvador, con durísimas represiones militares a los movimientos pacíficos de defensa de los derechos civiles (años setenta), y posteriormente durante los diez años que duró la guerra civil entre el ejército y el FMLN (1981-1991). No fueron pocas las universidades en América Latina que optaron por no entrar en ese tipo de conflictos, y que se mantuvieron al margen, siguiendo con su docencia y con su investigación como si no estuviera pasando nada. En el polo opuesto, otras optaron por identificarse plenamente con una causa política, en general, de izquierdas, hasta el punto de que se llegó a desdibujar su perfil institucional universitario.

Ellacuría no quiso que la UCA siguiera ninguno de estos dos modelos universitarios. Repensó completamente la función social de la universidad. Afirmó que la universidad debía ser una institución que entrara decididamente en el interior de los procesos históricos de transformación, y que aportase elementos para entender la realidad y para transformarla, todo ello "universitariamente" (Ellacuría, 1999a, p. 22; 1999c, p. 53) -tal como le gustaba decir-, y no como simple local donde se organizaran protestas civiles. Por ello, la universidad debía ser sumamente rigurosa con el método científico de sus investigaciones, que no podía abandonar nunca, e igualmente debía serlo con su docencia superior. 
Desde la universidad, el trabajo de Ellacuría como mediador en pleno conflicto bélico fue extraordinario, y efectivamente logró que se llegara a la paz, firmada en enero de 1992, aunque desgraciadamente él tuvo que ser asesinado para que tanto la comunidad nacional como la internacional vieran que acertaba en sus análisis políticos, completamente opuestos a falsas soluciones surgidas de una guerra civil (Dogget y Armada, 1995). Y desafortunadamente no se llegó a la paz justa, a la paz verdadera, que él propugnaba, aquella en la que se hubieran atacado de raíz las causas estructurales de la violencia, aunque no cabe duda de que la llegada de la democracia al país es ya un inicio (Sols, 2011b; Sols y Pérez, 2011).

En otro estudio (Sols, 2011a) expusimos que, para Ellacuría, los objetivos de la universidad son el análisis de la realidad y la transformación de esa realidad; las funciones de la universidad son la docencia, la investigación y la proyección social; sus variables son la contextualización y la universalización; el instrumento principal es la cultura, estructurada en ciencias, y para Ellacuría, la universidad tiene una nítida función política, no como apoyo a una u otra causa, sino como aportación rigurosa de elementos de análisis en los diferentes debates políticos (Sols, 2011a). Aquí analizaremos con exhaustividad este último punto: la aportación de Ellacuría al tema de la función social de la universidad -o la misión política de esta institución, como le gustaba denominarla-, y lo haremos partiendo de sus escritos, marcados por un dramático contexto histórico, pero al mismo tiempo redactados con una nítida pretensión de universalidad.

\section{RASGOS PRINCIPALES DE UN MODO ALTERNATIVO DE SER UNIVERSIDAD}

Ellacuría era consciente de que la institución universitaria, aun siendo joven en el continente americano, tenía defectos antiguos. Era una institución conservadora porque tendía a conservar el sistema vigente, aun cuando de ella salían interesantes aportaciones científicas y culturales; y era una institución elitista, dado que a ella sólo accedía una reducida minoría social por razones económicas - muchos jóvenes del país no podían pagarse unos estudios superiores porque trabajaban desde temprana edad de sol a sol- o por razones culturales - no se entendía que determinados sectores de la población entraran en la universidad. Ellacuría piensa en un modelo distinto de sociedad, más permeable a todas las capas y grupos sociales, y que se constituya en verdadero agente de cambio social. Para ello desarrolla los siguientes puntos:

\section{(A) Las mayorías oprimidas como horizonte}

Es sabido que Ellacuría fue uno de los pensadores más importantes de la denominada Teología de la Liberación. En su pensamiento, la idea de liberación es nuclear (Sols, 1999a, pp. 73-128; Sols, 1999b). Él, como otros muchos, considera que la libertad es un rasgo esencial de la humanidad, entendiendo por libertad -en palabras nuestras, no de Ellacuría- la facultad que tiene el hombre de poder construir su propio futuro de manera consciente, fruto de una deliberación iluminada por la razón. Cuando esta libertad se encuentra prisionera por determinadas estructuras o coyunturas, la acción humana moral consiste en liberar. Esta tarea de liberación parece no acabar nunca, dado que da la impresión de que las estructuras opresoras se sucedan época tras época, aunque sus modalidades vayan cambiando. La función social de la universidad consiste en participar en esos procesos históricos de liberación, tal como solía decir, "universitariamente". La universidad aporta un conocimiento científico, un universo cultural, un sistema docente, que todo él debería estar al servicio de ese camino hacia la libertad, que es el camino propiamente humano. En esta nueva concepción de universidad, esta institución ya no sería un elemento conservador, que tendiera a mantener el sistema tal como está, quizás aportando ligeros retoques, sino que debería ser el foro donde se analizara exhaustivamente qué hay de inhumano en la estructura política, social y económica, y qué transformaciones habría que implementar en ella para que la estructura estuviera al servicio del bien común.

Por ello, Ellacuría afirma que la misión de la universidad es al mismo tiempo universal y local: universal, porque toda universidad, en cualquier país del mundo, debería hacerse la misma pregunta, esto es, "¿Qué podemos aportar a los procesos de liberación necesarios en la sociedad o en el país donde se ubica nuestra universidad?"; y local, porque la respuesta a esa pregunta cambiará según el contexto histórico. Así, Ellacuría aporta 1/ un modo universal de proceder, y 2/ un ejemplo histórico concreto acerca de cómo aplicar ese método. En su caso, en su contexto - el de la América Latina de los años setenta y ochenta, y en particular, el de El Salvador - la gran inhumanidad que rodea a la universidad son las mayorías oprimidas por un sistema económico poscolonial, en el cual una minoría vive en la abundancia, con el apoyo del ejército nacional y de la Administración norteamericana, mientras que una débil clase media se siente incapaz de cambiar nada, y una mayoritaria clase pobre vive infrahumanamente y 
acaba por emigrar a los arrabales de la capital, o a los Estados Unidos, donde trabajará en condiciones de ilegalidad. "La realidad nacional y del pueblo salvadoreño - afirma Ellacuría- no sólo se presentan en términos de injusticia establecida y de violencia estructural, ni sólo en términos de dependencia internacional, sino como sociedad dividida, en que las partes tienen intereses contrapuestos, pues la minoría dominante no puede 'identificar' los suyos con los de las mayorías oprimidas, pues en su inmediatez contrapuesta son contrarios, activamente contrarios. Esto no significa necesariamente que no puedan encontrarse entre ambas partes intereses 'materialmente' comunes, 'coyunturalmente' comunes, pero sí marca una distinción fundamental, respecto de la cual hay que tomar partido" (Ellacuría, 1999c, p. 54). Y, obviamente, el partido a tomar no es otro que el de las mayorías estructuralmente oprimidas, fácilmente identificables en El Salvador de los años setenta y ochenta.

Esto no quiere decir que la función de la universidad sea sólo local; al contrario, en su compromiso histórico con su contexto social radica precisamente su universalidad.

\section{(B) La cultura como campo}

Ellacuría afirma que "el campo o ámbito de actividad universitaria así como su instrumental propio es la cultura". Reconoce a continuación que "la expresión no es muy feliz, porque la cultura propende a ser entendida como el patrimonio de las clases cultas, esto es, de las clases opresoras y de los individuos que están a su servicio y que reciben de aquéllas su apoyo y su sustento. Sin embargo, corregida de su carga clasista y de su carga puramente contemplativa, puede y debe mantenerse. La razón de mantenerse es, precisamente, la de subrayar la mismidad de la universidad y de impedir que ésta se desvirtúe en su tarea política" (Ellacuría 1999c, pp. 56-57). Ellacuría afirma que así como la agri-cultura, esto es, el cultivo del campo, es algo eminentemente práctico, aun cuando requiera teoría, así también la cultura en la que se mueve la universidad es cultivo de la realidad, en el sentido de "acción cultivadora y transformadora de la realidad", algo eminentemente práxico "por cuanto proviene de una necesidad de acción y debe llevar a una acción transformadora del propio sujeto y de su contorno natural e histórico", pero es también algo que requiere teoría. Los universitarios - ya sean profesores o estudiantesdeben ser "miembros cultivadores racionales de la realidad" (Ellacuría, 1999c, p. 57).
La cultura, que constituye "saber de la naturaleza y de la sociedad" en su necesaria implicación, y que "abarca el dominio de las técnicas transformadoras de la naturaleza, del hombre y de la sociedad", "exige un análisis estricto de la realidad nacional en cada momento de su proceso" (Ellacuría, 1999c, p. 57). En el pensamiento de Ellacuría, la cultura no es principalmente saber universal atemporal o ageográfico, sino la expresión de los procesos históricos de la realidad nacional, vehículo de expresión de las necesidades, intereses, sentimientos, apetencias y valores del pueblo. $Y$ es precisamente la cultura el instrumento que encuentra el pueblo para combatir la cultura dominante, la de las minorías que controlan el sistema.

\section{(C) La palabra eficaz como método}

No cabe duda de que, en la cultura, la palabra tiene una importancia central, dado que ella es "la comunicación recibida y comprendida de la cultura, reelaborada en la universidad" (Ellacuría, 1999c, p. 61). La palabra posee un poder mayor de lo que pueda parecer en un primer momento. En una primera aproximación, la palabra da impresión de fragilidad ante la realidad histórica, pero, sin embargo, puede convertirse en fuerza social, en poder material, en palabras de Marx recordadas por el propio Ellacuría: "la teoría se convierte en un poder material, siempre y cuando se adueñe de las masas" (cit. en Ellacuría, 1999c, p. 61). En el pensamiento de Ellacuría, la palabra es el método fundamental de actuación de la universidad. Mediante la palabra, la comunidad universitaria 1/ analiza científicamente la realidad, 2/ comunica los resultados de su investigación a la sociedad, 3/ juzga éticamente la realidad, y 4/ expone medios para transformarla; sin olvidar que, como decía Marx, la palabra tiene un poder de convicción enorme, que puede incluso arrastrar a las masas. No era esta última la palabra que buscaba Ellacuría, la palabra populista, la que despertaba el ardor de las multitudes, sino más bien esta otra: la universitaria, rigurosa, analítica, científica, una palabra que, además de estas características, tiene fuerza suficiente como para despertar la conciencia colectiva (Ellacuría, 1999c, p. 62).

\section{(D) La beligerancia como talante}

Ellacuría utiliza el adjetivo beligerante a la hora de calificar el talante de la universidad. Puede resultar sorprendente, pero en realidad no lo es. Si la universidad decide tomar parte en favor de los desfavorecidos del sistema económico, social y político en el que despliega su misión investigadora y docente - no al estilo de un sindicato o de un partido político, sino "univer- 
sitariamente"-, no cabe duda entonces de que debe ser crítica con ese sistema que estructuralmente produce marginación social, y no cabe duda tampoco de que ese sistema se va a defender de las críticas, por lo que necesariamente va a haber un combate - recordemos que beligerancia viene de la expresión latina bellum gerere, que significa hacer la guerra- entre la universidad y el sistema, un combate en el que puede haber desde debates tensos hasta el asesinato del rector de la universidad, como fue su caso. Así lo explicaba él: "El talante fundamental de la actividad universitaria, que tiene por horizonte la situación real de las mayorías oprimidas, no puede ser el del conformismo o el de la conciliación. Tiene que ser un talante beligerante. La beligerancia es, en nuestra situación, una característica importante del quehacer universitario. La universidad es, en nuestra situación, una de las pocas instituciones que puede de verdad ser beligerante. Y debe serlo" (Ellacuría, 1999c, p. 63). Pero más interesante aún es la argumentación que aporta para justificar esta posición: si la universidad quiere actuar siempre con la razón - ciencia, conocimiento, espíritu crítico, método riguroso-, y si el sistema social, económico y político imperante se vertebra en torno a la irracionalidad, entonces la universidad no puede menos que criticar ese sistema precisamente con la razón. "La razón, en efecto, es de por sí beligerante frente a la irracionalidad reinante, esto es, ante una estructuración de la realidad histórica en términos de flagrante irracionalidad, la universidad como cultivadora crítica de la razón no puede menos de ser y de sentirse beligerante". Y añade: "Si esta situación, además de irracional, es de positiva injusticia, la beligerancia está todavía más exigida" (Ellacuría, 1999c, p. 63); y no duda en calificar esa situación de "violencia institucional" y de "injusticia institucionalizada". ${ }^{2}$ Ellacuría insiste en que esto se ha de hacer de modo universitario, que tiene que ser una protesta que "no necesita de alaridos y de acciones violentas" (Ellacuría, 1999c, p. 64), pero eso no le ha de impedir ser verdaderamente activa, tensionada, dinámica, procesual, en pugna, siempre en busca de la objetividad, que no está reñida con la beligerancia.

\section{(E) El cambio estructural de la sociedad como objetivo}

La universidad puede parecer una institución cuya misión carga sobre lo teórico, pero no es así. La misión de la universidad es eminentemente práctica, y para alcanzar ese objetivo la teoría es su instrumento. El objetivo a alcanzar no es otro que la transformación de las estructuras, también de las personas que se forman en ella, pero primordialmente de las estructuras.
"El objetivo donde se concretan el horizonte y la finalidad de la actividad universitaria es la transformación estructural de la sociedad. Esto quiere decir que su actividad no va fundamentalmente dirigida a la transformación de las personas, sino a la transformación de las estructuras. No son, en principio, dos misiones contrarias, que se excluyan entre sí, la referencia a las personas y la referencia a las estructuras; pero de poner el acento en una de ellas cambiará notoriamente la dirección del trabajo universitario. Y lo que aquí se propone es cargar decididamente el acento sobre el problema estructural" (Ellacuría, 1999c, pp. 64-65). ¿Por qué Ellacuría da más importancia a lo estructural que a lo personal? ¿No es acaso la universidad una institución donde se forman personas, no sólo profesionalmente, sino en muchas otras dimensiones de su vida? La respuesta es sencilla para Ellacuría: si el objetivo de la universidad es el conocimiento y la transformación de la realidad, y si tenemos en cuenta que la realidad está constituida por estructuras, entonces debemos concluir que lo estructural tiene que pesar más que lo personal, sin descuidar, por supuesto, esta dimensión. En palabras de Ellacuría: "Si, efectivamente, la universidad busca últimamente la transformación de la realidad nacional, y la realidad nacional es formalmente de índole estructural, quien no busque directamente la acción sobre las estructuras no encontrará la realidad"; no olvidemos que para Ellacuría "la realidad en general es estructural, y la realidad social es especialmente estructural"; de nada serviría - argumenta - ir en busca de los individuos, porque con ellos no se aprehende la realidad ni en su totalidad ni en su complejidad: "No hay otra posibilidad de alcanzar una dimensión como es la de la realidad nacional, que la de ir en busca de sus estructuras; de lo contrario, la realidad nacional, perseguida a través de sus partes o de sus individuos, es evidentemente inalcanzable, y aunque fuera alcanzable, resultaría inoperable" (Ellacuría, 1999c, p. 65).

Antes de pasar al último de los rasgos de la universidad que defiende Ellacuría, el de la inspiración cristiana, conviene atender a la síntesis que hace de los cinco rasgos expuestos hasta aquí. Para Ellacuría, la universidad se mueve en una dialéctica tensionada por dos polos: 1/ la misión de contribuir a la transformación de la realidad histórica, y 2 / la fidelidad a su propia esencia universitaria. Él afirma que la universidad no puede inclinarse por uno de los dos polos, sino que debe mantener siempre la tensión entre ambos, si quiere ser lo que es, una universidad. "No hay contradicción 
alguna entre universidad y política; al contrario, ambas se necesitan mutuamente y se potencian. Hoy por hoy y en nuestra concreta situación, sería igualmente suicida abandonar las posibilidades universitarias en la búsqueda de la transformación nacional y no utilizar debidamente el potencial político de esas posibilidades universitarias" (Ellacuría, 1999c, p. 67).

\section{(F) La fe cristiana como fuente de inspiración}

La UCA es una universidad de inspiración cristiana, tal como ya hemos indicado más arriba. El 30 de septiembre de 1988, en el acto de graduación de una promoción de la UCA, Ellacuría recordaba que "esta universidad fue promovida por un grupo de cristianos, encuadrados en la Federación de Colegios Católicos, y encargada a los jesuitas para que la fueran desarrollando como universidad", por lo que "suele decirse que la UCA es una universidad de los jesuitas, no en el sentido que sea propiedad de ellos, sino en el sentido que han sido ellos sujeto principal de su conducción" (Ellacuría, 1999b, pp. 287-288). Ahora bien, para él, la inspiración cristiana de la universidad no debe ser algo que sólo esté en el orden de los estatutos, sino que tiene que ser una realidad práctica. Por ello, afirma que, así como Jesús de Nazaret no se anunció a sí mismo como Mesías, sino que anunció el Reino de Dios - algo se sobras probado por la cristología contemporánea ${ }^{3}$, así también "una universidad de inspiración cristiana lo será tanto más cuanto más contribuya a que se vaya haciendo realidad esa utopía anunciada y prometida por Jesús, que es el reino de Dios" (Ellacuría, 1999b, p. 290), un reino que, en palabras de Ellacuría, necesita ingenieros, economistas, administradores de empresa, contadores públicos, especialistas en computación (lo que hoy denominamos informáticos), químicos, psicólogos, sociólogos, filósofos, letrados, juristas y políticos, entre otros (Ellacuría, 1999b, pp. 290-291).

En la teología cristiana, el reino de Dios es un modelo de humanidad, un modelo de sociedad, aquel en el cual todos sus miembros son respetados en su dignidad como hombres. No es un modelo económico o político entre otros, sino una invitación a que cualquier modelo social esté al servicio del bien común. Así lo describe Ellacuría:

"Ese reino de Dios no se identifica con un modelo concreto de sociedad, sobre el cual Jesús nos dijo palabras muy precisas, pero sí reclama un modelo de sociedad en el cual todos los hombres, no sólo unos pocos, puedan disfrutar de las condiciones mejores para ser más hombres, más felices, más humanos; para que todos los hombres vivan dignamente como hijos del mismo Padre y hermanos entre sí; para que el mundo quede estructurado no desde la fuerza y el poder del pecado, sino desde la fuerza y el poder del amor divino y de la gracia; para que sea posible la plena libertad de todos, por un proceso de liberación de la concupiscencia, de la ley, del pecado y de la muerte; para que el mundo y la sociedad, en vez de ser un lugar inhóspito, donde predomine el egoísmo, el hombre sea un lobo para el hombre, se idolatren y absoluticen valores negativos, llegue a ser una nueva ciudad en la que cohabiten, sin dañarse, el león y el lobo con las ovejas, en donde las armas se conviertan en arados, en donde los pobres y los débiles sean los más favorecidos, en donde se busque el camino de la felicidad, más por el dar que por el recibir, en donde predomine el espíritu de las bienaventuranzas y de todo el sermón de la montaña" (Ellacuría, 1999b, p. 290).

El tono algo poético de este texto de Ellacuría, con imágenes tomadas incluso del libro de Isaías (Is 2,4; $65,25)$, se debe a que fue leído en el mencionado acto de graduación. En un evento de este tipo, los discursos tienden a un cierto brillo literario. No obstante, las imágenes poéticas no le impedían a Ellacuría enviar mensajes muy claros, con una prosa diáfana: "Los profesionales de la UCA tendrán inspiración cristiana cuando, además de hacer el mayor bien posible a los demás desde la profesión adquirida, tomen como tarea prioritaria la de buscar su bien, el de su familia y el de todos los demás, poniendo los ojos en lo que las mayorías populares necesitan para superar la pobreza, la marginalidad, la injusticia, la falta de libertad y participación" (Ellacuría, 1999b, p. 292). En esto, pues, consiste la inspiración cristiana de una universidad como la UCA: en poner toda la universidad al servicio de la construcción del reino de Dios, al servicio de la transformación de nuestra sociedad en otro modelo de sociedad donde todas las personas, sin excepción, vivan con sus derechos humanos habitualmente respetados; y en hacer todo eso "universitariamente". La palabra que resume todo este programa es liberación, una liberación que "se refiere tanto a las estructuras como a las personas, tanto a las necesidades de la naturaleza como a las opciones de la historia" (Ellacuría, 1999c, p. 90). Ahora bien, esta liberación no va solamente de dentro a fuera del sistema, de los integrados en él a los excluidos por él; también va de fuera a dentro: la liberación social nos viene de los excluidos, lo cual constituye una idea central del cristianismo. El cristianismo "ve en los más necesitados, de una forma u otra, a los redentores de la historia, a los privilegiados del reino de Dios, en oposición a los privilegiados 
de este mundo" (Ellacuría, 1999c, p. 91), y por ello Ellacuría no duda en citar en el acto de graduación un texto central del cristianismo, tomado del Evangelio de Mateo, que contiene estas palabras: "Venid, benditos de mi Padre; heredad el reino preparado para vosotros desde la creación del mundo. Porque tuve hambre y me disteis de comer, tuve sed y me disteis de beber, fui extranjero y me recogisteis, estuve desnudo y me vestisteis, estuve en la cárcel y fuisteis a verme... Os lo aseguro: Cada vez que lo hicisteis con un hermano mío de esos más humildes, lo hicisteis conmigo..." (Mt 25, 31ss).

\section{UN CAMINO NO EXENTO DE DIFICULTADES}

A los que trabajamos en la universidad, inmersos en la vorágine cotidiana, con clases, exámenes, investigaciones, acreditaciones de la calidad universitaria - nacionales e internacionales-, en medio de un mercado universitario cada vez más competitivo, todo esto nos puede sonar a música celestial, a discurso ingenuo cargado de buenas intenciones. No obstante, Ellacuría no era nada ingenuo. Dirigió un departamento durante diez años, y una universidad, la más prestigiosa de América Central, durante otros diez, y todo ello no en medio de la paz del campus, sino en plena revolución social, en plena guerra civil, intentando analizar la realidad nacional en la universidad, intentando aportar elementos para conducir al país hacia una paz justa (Sols, 2011b; Sols y Pérez, 2011). Ellacuría sabía que lo que escribía era difícil de realizar, pero al mismo tiempo, sabía que en esa utopía latía una verdad histórica que acabaría por ver la luz algún día.

En alguna ocasión enumeró las dificultades, tanto coyunturales como estructurales, para desplegar esta actividad universitaria de inspiración cristiana. Veamos algunas de ellas.

\section{(A) Condicionamientos de la universidad}

Ellacuría no podía ser más claro: "Es absolutamente obvio que la universidad es una realidad social y que, por serlo, está condicionada por la estructura de esa realidad, que es la sociedad" (Ellacuría, 1999c, p. 69). Estamos ante el más grande de los impedimentos estructurales con que la universidad se encuentra para desplegar esa utopía que antes hemos descrito: la universidad está en la sociedad, está a su servicio, vive de ella, por lo que acoge todas las contradicciones inherentes al sistema. No tiene ningún sentido hacer de la universidad una isla social, una excepción dentro del sistema. La universidad está y tiene que estar dentro de la sociedad que la rodea y que llena sus aulas y auditorios. "El intento de entenderse a sí misma como algo fuera de la sociedad, como algo inmune a las solicitaciones y a las presiones de la sociedad, es un intento ideologizado y, en definitiva, contraproducente para lograr de veras una cierta separación de lo que es la sociedad, en un momento dado. La universidad en un país socialista es algo distinto esencialmente a lo que es la universidad en un país capitalista, por más que muchos de sus elementos sean comunes y en apariencia los mismos". ${ }^{4}$

Ellacuría subraya tres factores de condicionamiento social:

En primer lugar, el factor económico. La universidad necesita mucho dinero para funcionar: sueldos a profesores y empleados, material técnico para la investigación científica, campus en buenas condiciones para el trabajo de los estudiantes, compra de libros y suscripción a revistas, viajes a congresos en el extranjero, y un largo etcétera. Este dinero tiene tres fuentes posibles: 1/ las matrículas de los alumnos, 2/ el Estado, y 3 / donaciones privadas. ${ }^{5}$ En los tres casos, los que dan dinero lo hacen si creen que la universidad les va a aportar algún beneficio: 1/ los estudiantes buscan una formación excelente y un título que sea reconocido nacional e internacionalmente; 2/ el Estado quiere ver cómo la universidad sigue las líneas que el gobierno ha trazado en su legislatura; y 3 / las empresas esperan algún tipo de beneficio futuro. Todo ello hace que la universidad pierda autonomía. Quizás aquí debamos recordar aquel cáustico editorial de Ellacuría, no pensado en la universidad, sino en la sumisión del gobierno a las multinacionales y a la oligarquía nacional: “¡A sus órdenes, mi capital!” (Ellacuría, 1991a). Ese podría ser el grito universitario por excelencia. Ellacuría reconoce que es un problema serio: “¿Podrá ser libre una universidad que depende de recursos económicos provenientes de fuentes, que pueden cerrarse a discreción? ¿Podrá una universidad que busca la transformación radical apoyarse en quienes no ven ventaja alguna para ellos en los caminos de esa transformación radical?" (Ellacuría, 1999c, p. 70).

En segundo lugar, tenemos lo que Ellacuría denomina la resistencia socio-política de los intereses dominantes. A menudo es sutil, mediante presiones a la universidad para que cambie de orientación, desacreditándola, a ella o a alguno de sus representantes; a veces, no tiene nada de sutil, arrojando hasta 25 bombas en la UCA, y matando a seis de sus más famosos jesuitas. Esta resistencia puede venir de fuera, sobre todo del Estado, que utiliza sus poderosos instrumentos mediáticos y represivos para intentar 
que la universidad se doblegue a su orientación política. Pero también puede venir de dentro: $1 /$ de su alumnado, "que no quiere ser perturbado en sus intereses actuales o futuros y que prefiere una preparación técnica, que no le cuestione ni respecto de sus compromisos actuales con la sociedad ni respecto de su futura incardinación ética en la estructura y en el dinamismo del país" (Ellacuría, 1999c, p. 71); 2/ de su profesorado, una resistencia que puede ser más pasiva que activa: "En cuanto el profesorado interviene como profesional -lo que no ocurre normalmente entre quienes están dedicados a tiempo completo a la universidad - en las exigencias empresariales al servicio de las clases dominantes o, al menos, de la estructura actual de la sociedad, se convierte 'profesionalmente' en hombre del sistema imperante" (Ellacuría, 1999c, p. 71), por lo que le resulta difícil a un profesor que vive del sistema erigirse en agente crítico de este; sin olvidar al profesorado de materias técnicas, que consideran que su docencia es aideológica, neutra ante la problemática social: "también se presenta la dificultad, porque parte del profesorado, el dedicado a las materias más técnicas, o no se percata de su responsabilidad política o no ve cómo vincularla con el carácter técnico de su propia disciplina" (Ellacuría, 1999c, p. 1); y 3/ en esta resistencia sociopolítica interna de los intereses dominantes, Ellacuría menciona también a las propias autoridades universitarias, que pueden ver en la politización de la universidad una fuente de problemas para el ejercicio de su gobierno corporativo.

Y en tercer lugar, tenemos la escasez de recursos aptos. En un país como El Salvador de los años setenta y ochenta, no era fácil encontrar profesores con una excelente formación académica, y cuando alguno despuntaba, fácilmente era captado por la empresa privada con un sueldo muy superior al que recibía en la universidad, cuando no por un gobierno que le ofrecía, no sólo un magnífico sueldo, sino también fama y poder. Por ello, Ellacuría lamenta que las universidades a menudo gestionen mal sus recursos, por ejemplo pagando salarios demasiado ajustados a los profesores - argumentando que no hay más fondos-, mientras que no tienen reparos en gastar dinero en nuevos edificios impresionantes, con fachadas que cortan la respiración, o en auditorios que impresionan a los padres de los alumnos el día de la graduación, una arquitectura que quiere competir con la empresa privada, pero que quizás hace que los alumnos de estratos inferiores de la sociedad no se sientan en la universidad como en su casa (Ellacuría, 1999c, p. 72).

\section{(B) Estructura burguesa de la universidad}

Ellacuría admite que la universidad tiene una estructura fundamentalmente burguesa. La universidad moderna, tal como la conocemos, se ha desarrollado de la mano de la clase burguesa, lejos, por un lado, de las clases bajas, a menudo analfabetas y con preocupaciones más urgentes que la de conocer la filosofía de Aristóteles, la Escuela de Salamanca o la Teoría de la Relatividad, y por otro, de las élites socioeconómicas, que no necesitan de la universidad para mantener su estatus. Estudiantes y profesores pertenecen mayoritariamente a la burguesía, esto es, a la clase media en sentido amplio, una clase bien instalada en el sistema, por lo que no se siente muy motivada a cambiarlo radicalmente, a riesgo de perder su posición acomodada. Se produce, por tanto, la extraña paradoja de que la universidad apunta a ser una institución al servicio de las clases oprimidas, siendo así que estas apenas nunca pisan sus aulas (Ellacuría, 1999c, pp. 72-73).

\section{(C) Resistencias internas}

Llevar a cabo el proyecto de universidad que defiende Ellacuría, con una misión política - o, si se prefiere, con una función social- que consiste en estudiar exhaustivamente la realidad para luego transformarla tomando partido por las mayorías estructuralmente desfavorecidas, es algo que supone "dejar atrás un esquema pretérito e ir creando uno nuevo" (Ellacuría, 1999c, p. 73), lo cual no es nada obvio, dado que todo sistema tiende a autoprotegerse, tal como pretendió hacer el ordenador "Hal" en la película 2001: una odisea en el espacio, con guión de Stanley Kubrick y de Arthur C. Clarke, cuando supo que lo iban a desactivar y reemplazar por otro. Los que sostienen el sistema, en este caso, universitario, tienden a perpetuarlo y a resistirse al cambio. Temen segar sus propios pies. "Las resistencias en este camino [de paso de un sistema universitario pretérito a otro nuevo] no vinieron sólo desde fuera; desde dentro mismo de la universidad, una serie de temores, de cautelas, de faltas de visión, dificultaron la marcha" (Ellacuría, 1999c, p. 73), aunque no llegaron a impedir la transformación que, en el caso de la UCA, se fue dando entre los setenta y los ochenta.

Por tanto, Ellacuría no era ingenuo. Era bien consciente de las dificultades, lo que no le impedía estar convencido al mismo tiempo de que la transformación universitaria era posible, como veremos a continuación. 


\section{UNA UNIVERSIDAD DISTINTA ES POSIBLE}

Una vez clarificados el horizonte a perseguir y las dificultades reales para llegar a él, es el momento de abordar las posibilidades reales de realización de la utopía. Ellacuría era fundamentalmente realista. Su realismo consistía en intentar entender en profundidad la realidad, yendo más allá de lo que él denominaba ideologizaciones, yendo más allá de los discursos imperantes, e intentando atisbar la utopía a perseguir y el camino para llegar a ella.

Ellacuría distinguía la ideología de la ideologización. La ideología es un pensamiento vertebrado en torno a una idea: la idea de la centralidad de lo humano (humanismo), la idea de la centralidad de los derechos del individuo (liberalismo), la idea de la necesidad de que la clase proletaria alcance el poder económico y político (socialismo), la idea de la centralidad de la nación (nacionalismo), la idea de igualar a la mujer con el hombre (feminismo) o la idea de la prioridad del medio ambiente (ecologismo), entre otros muchos ejemplos. La ideologización, en cambio, consiste en un engaño, esto es, en decir algo que socialmente suena bien, " $A$ ", cuando en realidad se está pensando en algo que no tendría tan buena aceptación social, "B". La ideologización " $A$ " oculta el pensamiento "B". Para Ellacuría, "la ideologización añade a la ideología el que inconsciente e indeliberadamente se expresen visiones de la realidad, que lejos de manifestarla, la esconden y deforman con apariencia de verdad, en razón de intereses que resultan de la conformación de clases o grupos sociales y/o étnicos, políticos, religiosos, etc." (Ellacuría, 1991b, p. 99).

Precisamente es frente a esta ideologización que oculta la verdad de la realidad frente a la que debe actuar lo que Ellacuría denomina la función liberadora de la filosofía a través de su misión crítica. La función de criticidad consiste en el desenmascaramiento de los engaños ideológicos, de las injusticias con apariencia de justicia. Ellacuría recuerda que "toda filosofía nueva ha surgido por insatisfacción del filósofo o de la escuela filosófica con todo o casi todo lo que ha antecedido en el terreno filosófico. Los grandes filósofos han sido siempre unos grandes inconformes con el pensamiento recibido, y no sólo están preparados mentalmente para grandes gigantomaquias, sino que su talante mismo es esencialmente crítico y está preparado para distinguir la verdad de sus apariencias, lo probado de lo no probado, etc." (Ellacuría, 1991b, p. 100).
Ahí reside el horizonte de la universidad, su utopía: en contribuir universitariamente a transformar la realidad desenmascarando las ideologizaciones dominantes y liberando a las mayorías oprimidas de su yugo, una liberación que atañe tanto a lo natural — ciencias naturales - como a lo social - ciencias sociales-, sin olvidar las disciplinas humanísticas ni las de tipo instrumental. Entre la utopía y las dificultades reales están las posibilidades. Ellacuría las desarrolla con realismo. Está convencido de que la universidad, en concreto, la UCA, puede caminar hacia esa utopía. Aquí sólo las esbozaremos, en parte porque quizás tengan más interés en el contexto histórico que vivió Ellacuría, aunque tampoco queremos obviarlas porque sí tienen un punto de interés universal, que reside en el método de trabajo: $1 /$ descripción de la utopía humanista, 2/ toma de conciencia de las dificultades reales, y 3 / estudio de las posibilidades reales de alcanzar históricamente la utopía. ${ }^{6}$

1. Hay que querer ir hacia la utopía. Este querer -en filosofía hablaríamos de voluntad - tiene que ser auténtico, real, institucional. No debe ser sólo un discurso atractivo para el día de la bienvenida a los alumnos de primer curso y para el día de la graduación final, sino el horizonte que la universidad realmente desea alcanzar.

2. Hay que estar convencidos de la importancia que la universidad tiene en el futuro del país en el cual desarrolla su actividad.

3. Hay que detectar qué recursos se tienen ya para caminar en esa dirección, y tratar de sacarles el máximo provecho.

4. A la hora de seleccionar al alumnado, la utopía debe estar presente. De algún modo, hay que intentar seleccionar a aquellos candidatos a alumnos de la universidad que compartan esa utopía. Recordemos que estamos hablando de una universidad de inspiración cristiana, por tanto, privada, no pública, por lo que la dirección de la universidad tiene libertad para decidir los criterios con los que se aceptan a unos $u$ otros estudiantes.

5. Hay que procurar tener en cuenta la utopía a la hora de contratar profesores, que deben ser no sólo excelentes profesionalmente -esto es clave para que la universidad sea seria-, sino también sensibles al horizonte perseguido - esto es clave para que la universidad camine efectivamente hacia su utopía. No se trata de que todos tengan la misma ideología política, lo cual sería nefasto para la necesaria pluralidad del cuerpo 
docente, pero sí que deseen contribuir a la búsqueda de la utopía de esa universidad.

6. Hay que procurar ir ganando en autonomía universitaria. Un plan que propone Ellacuría, mediante las cuotas diferenciadas - cada alumno paga una cantidad por la matrícula en función de la renta familiar-, consiste en hacer que el alumno se comprometa a devolver en el futuro el dinero que la universidad puso en su formación, en cuanto gane lo suficiente para hacer efectiva esa devolución progresiva.

7. Dado que la universidad tiene una triple función -investigación, docencia y proyección social-, hay que procurar encaminar cada una de ellas poco a poco en la dirección del horizonte. La investigación: convendría que todos los proyectos de investigación, de todas las carreras, tuvieran como horizonte el de la universidad.

8. Hay que ir reformando la docencia, no tanto en la modernización de sus recursos tecnológicos, sino en dirección al horizonte de la universidad.

9. La proyección social debe ir encaminada poco a poco a que, a través de la cultura, la producción intelectual de la universidad beneficie al conjunto de la sociedad, empezando por los grupos más desfavorecidos.

10. La universidad debe ir constituyéndose poco a poco en conciencia de la sociedad, de manera que la conciencia colectiva de la nación vaya siendo cada vez más humana y justa, y de manera que esta transformación vaya cristalizando en estructuras objetivas.

Ellacuría no dudaba de que era posible lograr una universidad distinta.

\section{CONCLUSIÓN}

Como hemos podido ver, la concepción de universidad de Ignacio Ellacuría es claramente alternativa a dos modelos que abundan por Occidente: 1 / la universidad que rehúye entrar como institución en debates sociales o políticos, que prefiere mantener su excelencia acadé- mica, y que, como mucho, admite que ciertos profesores $u$ organizaciones estudiantiles se movilicen en una dirección u otra, sin que nada de ello implique a la institución como tal; y 2/ la universidad convertida en un centro de agitación política contra la dictadura o contra una clase dirigente vista como injusta, olvidando su ser universitario. Lejos de estos dos modelos, uno alejado del mundo y el otro alejado del rigor universitario, Ellacuría promueve un modelo de universidad que tome conciencia de su función social, de su misión política, que no es otra que la de analizar exhaustivamente la realidad histórica en la cual la universidad en cuestión tiene incidencia, para tratar de transformarla. Obviamente, esta transformación no se puede hacer a ciegas; ni siquiera se puede admitir que cada profesor tenga su propio horizonte, independiente de los horizontes de los demás. Una universidad como la UCA, esto es, de la Compañía de Jesús y de inspiración cristiana, debe saber antes que nada qué modelo de hombre y de sociedad pretende construir, un modelo inspirado en la antropología cristiana - todos los hombres tenemos la misma dignidad por el hecho de ser todos hijos de Dios Padre, y nuestra dignidad es superior a la de cualquier otra criatura de la naturaleza, lo cual no nos da derecho a maltratarla, sino que nos hace responsables de ella (Sols, 2013, pp. 33-46; Sols, 2014, pp. 371-392).

Este modelo es universal y al mismo tiempo local. Es universal, dado que la misma fe cristiana inspira a todos los centros superiores de la Compañía de Jesús del mundo, tal como ha sido defendido por los últimos tres Prepósitos Generales, Pedro Arrupe, PeterHans Kolvenbach y Adolfo de Nicolás (cfr. Kolvenbach, 2000). ${ }^{7}$ Y este modelo es local, nacional, contextuado, dado que la universidad está al servicio de la sociedad en la cual está ubicada: El Salvador, Centroamérica, en el caso de la UCA; otra región, otra nación, en el caso de otras universidades.

Por ello, aun cuando el trabajo de docencia, de investigación y de proyección social de una universidad pueda parecer primordialmente teórico, es en realidad eminentemente práctico, o mejor dicho, pretende ser una contribución fundamental al necesario momento teórico de los procesos práxicos de transformación histórica.

\section{NOTAS}

[1] Para una presentación sintética de la vida de Ignacio Ellacuría y de su contexto histórico, cfr. Sols, 1998; Sols, 1999a, pp. 19-71.

[2] Ellacuría toma la expresión violencia institucionalizada - aunque él prefie- ra hablar de violencia institucionalde los documentos de la II Conferencia Episcopal Latinoamericana, que tuvo lugar en Medellín, Colombia, en 1968, y que está considerada como el momento fundacional de la Teología de la
Liberación. Cfr. II Conferencia General del Episcopado Latinoamericano: Iglesia y liberación humana, II, 16.

[3] Recordemos las cristologías de José Ignacio González Faus (La humanidad nueva), de Jon Sobrino (Jesucristo li- 
berador) o de John P. Meier (Un judío marginal), entre otras.

[4] Ellacuría publicó este texto en 1974, en plena Guerra Fría, período en el que las diferencias entre universidades de países socialistas y de países capitalistas eran llamativas.

[5] De hecho, Ellacuría olvida una cuarta fuente: encargos técnicos de empre- sas y del propio Estado a la universidad, que no son propiamente donaciones ni subvenciones, sino compra de servicios.

[6] La enumeración que sigue es nuestra, a partir de Ellacuría, 1999c, pp. 74-88.

[7] Cuando estamos a punto de entregar defintivamente este artículo a la revista Arbor, la Congregación General 36 de la Compañía de Jesús, reunida en Roma, acaba de nombrer Prepósito General al P. Arturo Sosa. Todavía es pronto para conocer exhaustivamente su posición acerca de este tema.

\section{BIBLIOGRAFÍA}

Burke, K. y Lassalle-Klein, R. (eds.). (2006). Love that Produces Hope: The Thought of Ignacio Ellacuría. Collegeville: Michael Glazier / Liturgical Press.

Dogget, M. y Armada, P. (1995). Una muerte anunciada en El Salvador. Madrid: PPC.

Ellacuría, I. (1991a). A sus órdenes, mi capital. En Ellacuría, I. Veinte años de historia en El Salvador (1969-1989). Escritos políticos (vol. I.). San Salvador: UCA Editores, pp. 649-656.

Ellacuría, I. (1991b). Función liberadora de la filosofía. En Ellacuría, I. Veinte años de historia en El Salvador (1969-1989). Escritos políticos (vol. I.). San Salvador: UCA Editores, pp. 93-121.

Ellacuría, I. (1999a). Discurso de la Universidad Centroamericana José Simeón Cañas en la firma del contrato con el Banco Interamericano de Desarrollo (BID). En Ellacuría, I. Escritos universitarios. San Salvador: UCA Editores, pp. 19-26.

Ellacuría, I. (1999b). La inspiración cristiana de la UCA en la docencia. En Id., Escritos universitarios (pp. 287-295). San Salvador (El Salvador): UCA Editores. [Primera publicación en Planteamiento universitario, vol. 1989, pp. 195-200].

Ellacuría, I. (1999c). Diez años después, ¿̇es posible una universidad distinta?. En Ellacuría, I. Escritos universitarios. San Salvador: UCA Editores, pp. 49-92.

Ellacuría, I. (1999d). Una universidad centroamericana para El Salvador. En Ellacuría, I. Escritos universitarios. San Salvador: UCA Editores, pp. 93-103.

Ellacuría, I. (1999e). Funciones fundamentales de la universidad y su operativización. En Ellacuría, I. Escritos universitarios. San Salvador: UCA Editores, pp. 105-167.

Ellacuría, I. (1999f). Universidad y política. En Ellacuría, I. Escritos universitarios. San Salvador: UCA Editores, pp. 169-202.

Ellacuría, I. (1999g). Universidad, derechos humanos y mayorías populares. En Ellacuría, I. Escritos universitarios. San Salvador: UCA Editores, pp. 203-219.

Ellacuría, I. (1999h). Discurso de graduación en la Universidad de Santa Clara. En Ellacuría, I. Escritos universitarios. San Salvador: UCA Editores, pp. 221-228.

Ellacuría, I. (1999i). La UCA ante el doctorado concedido a Monseñor Romero. En Ellacuría, I. Escritos universitarios. San Salvador: UCA Editores, pp. 229-243.

Ellacuría, I. (1999j). Veinte años de servicio al pueblo salvadoreño. En Ellacuría, I. Escritos universitarios. San Salvador: UCA Editores, pp. 245-251.

Ellacuría, I. (1999k). Los retos del país a la UCA en su vigésimo aniversario. En Ellacuría, I. Escritos universitarios. San Salvador: UCA Editores, pp. 253-272.

Ellacuría, I. (1999I). Hacia un desarrollo liberador de los pueblos. En Ellacuría, I. Escritos universitarios. San Salvador: UCA Editores, pp. 273-285.

Kolvenbach, P. H. (2000). El servicio de la fe y la promoción de la justicia en la educación universitaria de la Compañía de Jesús de Estados Unidos. Discurso en la Universidad de Santa Clara, California, Estados Unidos, 6 de octubre de 2000. Revista de Fomento Social, 55, pp. 595-614.

Senent de Frutos, J. A. (1998). Ellacuría y los derechos humanos. Bilbao: Desclée de Brouwer.

Sols, J. (1998). El legado de Ignacio Ellacuría. Barcelona: Cristianisme i Justícia.
Sols, J. (1999a). La teología histórica de lgnacio Ellacuría. Madrid: Trotta.

Sols, J. (1999b). Lo cristiano de la liberación. En Sobrino, J y Alvarado, R. (eds.). Ignacio Ellacuría, "aquella libertad esclarecida". Santander: Sal Terrae, pp. 161-176.

Sols, J. (2003). Quan la fe interpreta i transforma. Barcelona: Claret.

Sols, J. (2011a). Las universidades y la vida pública. En Etxeberria, X y Hortal, A. (eds.). Profesionales y vida pública. Bilbao: Desclée de Brouwer, pp. 205-224.

Sols, J. (2011b). El pensamiento de Ellacuría en torno a la reconciliación. En Senent de Frutos, J. A., Sols Lucia, J., Torralba, F., Carreras, I., Camdessus, M.Byron, W. J., Giménez García, J. González, E. Wiesenthal, M., Calaf, R. M., Papini, R. y Larrañaga, X. ¿Hacia una nueva era? Bilbao: Publicaciones de la Universidad de Deusto, pp. 41-98. Disponible en http:// www.deusto-publicaciones.es/deusto/ pdfs/forum/forum24.pdf

Sols, J. (2013). Cinco lecciones de pensamiento social cristiano. Madrid: Trotta.

Sols, J. (2014). Ecología. En Sols, J. (ed.). Pensamiento social cristiano abierto al siglo XXI. A partir de la encíclica Caritas in veritate. Santander: Sal Terrae.

Sols, J. y Pérez, J. C. (2011). El pensamiento de Ignacio Ellacuría acerca de procesos históricos de reconciliación política. Análisis de siete conceptos: conflicto, violencia, causa, diálogo, pacificación, paz, reconciliación. Pensamiento. Revista de Investigación e Información Filosófica, 67, 251, pp. 103-124. 